\title{
Assessment of Women's Knowledge, Performance and Attitude towards Pap Smear Test in Sabzevar, Iran (2015)
}

\author{
Bibi Leila Hoseini ${ }^{1}$, Nematullah Shomoossi², \\ Mohammad Hassan Rakhshani ${ }^{3,4}$, Reihane Beinaghi ${ }^{5}$ \\ ${ }^{1}$ Department of Midwifery, School of Medicine, Sabzevar University of Medical Sciences, Sabzevar, Iran \\ ${ }^{2}$ Department of General Courses, School of Medicine, Sabzevar University of Medical Sciences \\ 3Ph.D in Biostatistics, Department of Biostatistics, School of Public Health, \\ Sabzevar University of Medical Sciences, Sabzevar, Iran \\ ${ }^{4} \mathrm{PhD}$ in Biostatistics, Iranian Research Center on Health Aging, School of Public Health, \\ ${ }^{5}$ Public Health graduate, School of Public Health, Student Research Committee, \\ Sabzevar University of Medical Sciences, Sabzevar, Iran
}

\section{SUMMARY}

Cervical cancer is considered as a common female genital cancer. It is also recognized as the second most frequent cause of cancer-related death among women. It is estimated that in Iran cervical cancer ranks the $4^{\text {th }}$ most frequent cancer in women. Therefore, with regard to the importance of Pap smear in preventing cervical cancer, together with the impact of women's knowledge and attitude towards Pap smear performance, we aimed to assess women's knowledge, performance and attitude towards Pap smear test in Sabzevar, Iran. This descriptive cross-sectional study was conducted on 385 women referred to health care centersand gynecological offices in Sabzevar, Iran. A questionnaire designed and validated by Abedian and Dormohamadi (2013) was used for data collection. Descriptive and analytic statistics were used for analysis.

The mean scores of knowledge, attitude and performance were reported to be $2.1 \pm 0.10,66 \pm 0.43$, and $0.70 \pm 0.06$, respectively. Participants' age, education and their spouses' education were found as effective variables in their Pap smear knowledge, attitude and performance.

The findings indicated that despite the fact that participants' knowledge and performance regarding cervical cancer were not desirable, their attitude was rather acceptable. Therefore, education and training of women in health centers by physicians together with engaging the health staff in improving women's knowledge, performance and attitude towards cervical cancer prevention and treatment are highly recommended.

Key words: knowledge, attitude, performance, pap smear, Sabzevar

Corresponding author:

Reihane Beinaghi

e-mail: r.beinaghi@gmail.com 


\section{INTRODUCTION}

Cervical cancer is considered as one of the common types of cancer of female genitalia (1-3), and the second most frequent cause of cancer-related death (4). Each year, more than half a million of women are diagnosed with cervical cancer, $80 \%$ of which relate to underdeveloped countries $(5,6)$. Therefore, it is a significant health problem in underdeveloped countries $(2,3)$. In Iran, the prevalence of this disease is $6.64 \%$, and it is estimated to be the $4^{\text {th }}$ most frequent cancer in women $(5,7)$. The average age of diagnosis of cervical cancer is 52 years $(2,3)$, but its peak ranges across the 35-39 and 60-64 year-old groups (2).

Some of the relevant risk factors include the young age at the first coitus ( $<16$ years old), having multiple sexual partners, smoking, grand parity, low socio economic status, and immune system deficiency (7). However, most women with early-stage cervical cancer are asymptomatic. The only diagnosis route is to assess the cytology of cervix (2). Due to the long precancerous stage, the presence of an appropriate screening program and effective treatment of precancerous lesions, cervical cancer can be conveniently prevented (5). If it is diagnosed and treated in the precancerous stage, the survival rate of the patients could be enhanced up to $90 \%(5)$ or even to $100 \%(2,3)$. This highlights the importance of cervical screening.

The screening is normally performed by a Pap smear test (2) but the increasing number of deaths due to cervical cancer can indicate disinclination to perform Pap smear especially in underdeveloped countries. The reasons may include unavailability of Pap smear in these countries, being unifinormed about the presence of such atest, lack of a physician's advice, stress, fear of catching cervical cancer, sense of pain during the test, and being ashamed of doing it (4, 5). If the test is not performed or performed irregularly, the risk of catching cervical cancer increases 26 fold (8). ACOG has recommended that the Pap smear test should start 3 years following the initiation of sexual intercourse. If it has been normal during three continuous tests, they would recommend doing it every 2-3 years after the age of 30 (2).

Several studies reported different findings related to women's knowledge and performance about Pap smear. Zareai found that $76 \%$ of subjects had a history of Pap smear test, but only $36 \%$ of the participants (131 people) had Pap smear performed once (3). Asgharnia et al. found that $20.4 \%$ of the participants had Pap smear performed; the mean score of women's attitude who had Pap smear performed was significantly higher than in the other group (4). Abedian and Dormohamadi also showed that most of the participants had moderate knowledge and good performance of Pap smear (9). However, Ramezani Tehrani found that $60.8 \%$ of women knew about cervical cancer; among the participants, $41.6 \%$ had Pap smear performed once and $21.1 \%$ declared a time lapse of more than two years from their last test (10). To sum up, knowledge is certainly one of the most important factors in predicting health behaviors and administrating screening methods. Attitude is also recognized as an essential factor in applying predictive behaviors. Undoubtedly, cancer control by the use of screening methods may not turn to be possible without positive attitude (9).

\section{AIMS}

With regard to the importance of performing Pap smear in preventing cervical cancer, and the impact of women's knowledge and attitude on their tendency to undergo Pap smear and lack of previous studies with similar aims in Sabzevar, Iran, the researchers aimed to investigate and determine the women's knowledge, attitude and performance of Pap smear in Sabzevar City, Iran.

\section{PATIENTS AND METHODS}

This descriptive cross-sectional study was conducted on 385 women referred to the health care centers, mosques and physicians' offices in Sabzevar, Iran, in 2015. The research proposal was approved by the Student Research Committee as well as the Ethics Committee of Sabzevar University of Medical Sciences, Iran (Ethical code: IR.MEDSAB.REC. 13394.35). At first, all health care centers, mosques and physicians' offices in the city were listed, then they were divided into some stratums. Some places in each stratum were selected randomly. Then, participants in selected places entered the study by simple sampling. Eventually, informed consent was obtained to make sure that the participants' rights were taken into account and respected. Finally, the questionnaires were given and completed.

The inclusion criteria included residents of Sabzevar with an age range of 15-65 years, being married and showing good mental status. The ex- 
clusion criteria included the participant's cervical cancer or the same disease in any of her first class family members, and being employed in medical professions. The applied tool was a questionnaire designed by Abedian et al. (9). The questionnaire included five sections: section A containing five questions related to demographic characteristics, section $B$ containing eight questions about knowledge (scorable by assigning correct response $=1$, false response $=$ zero), with a range of $0-8$; section $\mathrm{C}$ containing 37 questions related to attitude (questions derived from Champion's health beliefs, which includes six general sub-dimensions: perceived susceptibility related to cervical cancer, perceived seriousness related to cervical cancer, perceived benefits of Pap smear, perceived obstacles for Pap smear, motivation for health, self-efficacy of Pap smear), with a score range of $37-111$; section D containing six questions in the field of performance (correct response $=1$, false response $=0$ ), with a minimum and a maximum scores of 0 and 6 , respectively. Finally, Section E containing nine questions related to the history of obstetrics and midwifery. Researchers used the Cronbach's alpha to determine the questionnaire reliability; its validity was also approved through content validity. Data were analyzed through descriptive (frequency, mean $\pm \mathrm{SD}$ ) and analytical (linear regression) statistics by SPSS-20; $\mathrm{p}<0.05$ was considered significant.

\section{RESULTS}

A total of 385 women participated in the study. As for their education, 129 women (33.5\%) had high school education; also, spouses of 122 participants (29.1\%) had high school education. Most of them $(83.9 \%)$ were housewives and the majority of their spouses $(55.1 \%)$ were self-employed. The mean age $( \pm$ standard deviation) of the participants was 35.7 ( \pm 12.6) years; they were married at the age of $19( \pm 4.5)$. The average number of their gravidity and parity were $2.54( \pm 1.9)$ and $2.13( \pm 1.8)$, respectively. As reported, $56.66 \%$ of the participants did not have previous infectious vaginal discharge. Also, $76.4 \%$ of them believed that a physician is the best person for Pap smear sampling. Most of the participants (71.2\%) declared that the Pap smear was a suitable tool to prevent cervical cancer. They also believed in the training sessions of health centers $(30.4 \%)$ and physicians $(29.4 \%)$ as the best educational sources on
Pap smear.

The mean scores of knowledge, attitude and performance are shown in Table 1. The knowledge score was not desirable. While it ranges between 0-8, the obtained score by 111 participants $(28.8 \%)$ was zero. The obtained knowledge score of more than $71 \%$ of the participants did not even reach the median score. The perceived susceptibility to cervical cancer sub-dimension was better, since more than $59 \%$ of the participants were able to acquire the median of this range. However, in perceived seriousness related to cervical cancer, $60 \%$ of the participants, and in perceived benefits of Pap smear subdimension more than $64 \%$ of them acquired scores less than median for each subdimension's range. The perceived obstacle for Pap smear subdimension was also better; $50 \%$ of the participants were able to acquire the maximum score of 24. However, the "motivation for health" subdimension was not desirable. While it ranges between 6-18, just a few more than $95 \%$ of the participants have acquired the maximum score of 6 . In the 'selfconfidence' subdimension, $50 \%$ acquired the score of 16. The 'attitude' score was 66 , which is rather intermediate. Based on the obtained findings regarding the three mentioned dimensions, it was found that participant's performance was not desirable. Thus, the maximum score of performance for $82.3 \%$ of the participants was 3 . With regard to 'performance' range between $0-6$, the results demonstrated a really weak performance level.

Linear regression was used to assess effective factors for the main studied variables. The only effective variables for knowledge, attitude and performance were age, participants' education and their spouses' education (Table 2). Upon investigating the factors affecting the perceived seriousness of cervical cancer, no linear or non-linear model was found to be fitting, and goodness of fit was rejected for all models; accordingly, we were unable to precisely investigate the factors and the magnitude of their effects. In other words, the goodness of fit was rejected.

For example, participants' age and their spouse's education impacted their Pap smear performance. One year increase of age enhanced the Pap smear performance score by 0.037 ; also, the higher the spouse's education, the lower the performance score by 0.0242 . However, the standardized coefficient (regarding the absolute value) indicated that age was more effective than the education of the participant's spouse. 
Table 1. Descriptive indices of knowledge, attitude and performance

\begin{tabular}{|c|c|c|c|c|c|c|}
\hline & Variables & $\begin{array}{l}\text { Mean } \\
\pm S \text {. E }\end{array}$ & $\begin{array}{l}\text { Percentile } \\
25\end{array}$ & $\begin{array}{l}\text { Percentile } \\
50 \\
\end{array}$ & $\begin{array}{l}\text { Percentile } \\
75 \\
\end{array}$ & $\begin{array}{l}\text { Score } \\
\text { Range }\end{array}$ \\
\hline & Knowledge & $\begin{array}{l}2.1 \pm \\
0.10\end{array}$ & 0 & 2 & 4 & $0-8$ \\
\hline & $\begin{array}{c}\text { Perceived susceptibility to } \\
\text { cervical cancer subdimension }\end{array}$ & $\begin{array}{l}6.6 \pm \\
0.14\end{array}$ & 4 & 6 & 8 & $4-12$ \\
\hline & $\begin{array}{l}\text { Perceived seriousness related } \\
\text { to cervical cancer subdimension }\end{array}$ & $\begin{array}{l}4.3 \pm \\
0.10\end{array}$ & 3 & 4 & 6 & $3-9$ \\
\hline & $\begin{array}{c}\text { Perceived benefit of Pap } \\
\text { smear subdimension }\end{array}$ & $\begin{array}{c}7 \pm \\
0.11 \\
\end{array}$ & 5 & 6 & 10 & $5-15$ \\
\hline$\stackrel{0}{\underline{D}}$ & $\begin{array}{c}\text { Perceived obstacle forPap } \\
\text { smear subdimension }\end{array}$ & $\begin{array}{c}24.4 \pm \\
0.24\end{array}$ & 22 & 24 & 27 & $11-33$ \\
\hline & $\begin{array}{c}\text { Motivation for health } \\
\text { subdimension }\end{array}$ & $\begin{array}{l}6.7 \pm \\
0.07\end{array}$ & 6 & 6 & 7 & $6-18$ \\
\hline & $\begin{array}{l}\text { Self-efficacy of Pap } \\
\text { smear subdimension }\end{array}$ & $\begin{array}{l}17 \pm \\
0.25\end{array}$ & 14 & 16 & 22 & $8-24$ \\
\hline & Total score ofattitude & $\begin{array}{l}66 \pm \\
0.43\end{array}$ & 60.25 & 66 & 71 & $37-111$ \\
\hline & Performance & $\begin{array}{c}0.70 \pm \\
0.06\end{array}$ & 0.63 & 0.65 & 0.76 & $0-6$ \\
\hline
\end{tabular}

Table 2. Linear regression of studied variables and explanatory variable

\begin{tabular}{|c|c|c|c|c|c|c|}
\hline & Studied variables & $\begin{array}{c}\text { Explanatory } \\
\text { variable }\end{array}$ & Coefficient & S. E & $\begin{array}{c}\text { Standardized } \\
\text { coefficient }\end{array}$ & P-value \\
\hline \multirow{2}{*}{\multicolumn{2}{|c|}{ Knowledge }} & Education level & 0.438 & 0.104 & 0.276 & $<0.001$ \\
\hline & & $\begin{array}{c}\text { Spouse's } \\
\text { education level }\end{array}$ & 0.264 & 0.103 & 0.167 & 0.011 \\
\hline \multirow{12}{*}{ | } & \multirow{2}{*}{$\begin{array}{l}\text { Perceived susceptibility } \\
\text { to cervical cancer } \\
\text { subdimension }\end{array}$} & Age & 0.047 & 0.012 & 0.224 & $<0.001$ \\
\hline & & Education level & -0.408 & 0.118 & -0.189 & 0.001 \\
\hline & \multirow{2}{*}{$\begin{array}{c}\text { Perceived benefits of } \\
\text { Pap smear } \\
\text { subdimension }\end{array}$} & Education level & -0.322 & 0.123 & -0.177 & 0.009 \\
\hline & & $\begin{array}{c}\text { Spouse's } \\
\text { education level }\end{array}$ & -0.333 & 0.123 & -0.183 & 0.007 \\
\hline & \multirow{2}{*}{$\begin{array}{c}\text { Perceived obstacle for } \\
\text { Pap smear } \\
\text { subdimension }\end{array}$} & Age & 0.042 & 0.021 & 0.112 & 0.039 \\
\hline & & $\begin{array}{c}\text { Spouse's } \\
\text { education level }\end{array}$ & 0.654 & 0.209 & 0.168 & 0.002 \\
\hline & \multirow{2}{*}{ Motivation for health } & Age & -0.029 & 0.007 & -0.251 & $<0.001$ \\
\hline & & Education level & -0.214 & 0.068 & -0.179 & 0.002 \\
\hline & \multirow{2}{*}{$\begin{array}{c}\text { Self-efficacy of Pap } \\
\text { smear subdimension }\end{array}$} & Age & 0.059 & 0.022 & 0.151 & 0.007 \\
\hline & & Education level & -0.759 & 0.224 & -0.189 & 0.001 \\
\hline & \multirow{2}{*}{ Total score of attitude } & Age & 0.133 & 0.036 & -0.174 & 0.002 \\
\hline & & Education level & -1.176 & 0.372 & 0.101 & 0.037 \\
\hline & \multirow[b]{2}{*}{ Performance } & Age & 0.037 & 0.008 & 0.239 & $<0.001$ \\
\hline & & $\begin{array}{c}\text { Spouse's } \\
\text { education level }\end{array}$ & -0.242 & 0.091 & -0.132 & 0.008 \\
\hline
\end{tabular}




\section{DISCUSSION}

The present findings indicated that the participants' knowledge, regarding cervical cancer, was not desirable, which is, however, inconsistent with the studies of Zareai (3) and Abedian and Dormohamadi (9). Based on the latter, $76 \%$ of participants were familiar with Pap smear tests showing weak knowledge $(22.8 \%)$, moderate knowledge (64.8\%), and good knowledge (12.4\%) (3). Abedian and Dormohamadi also reported participants' knowledge level as good $(13.8 \%)$, moderate (59.4\%), and weak (26.8\%) (9). Since the researchers did not have optimal cut off points for classifying knowledge, attitude and performance, they divided the score range into three identical ranges. Although this type of classification is one of the common ways, it may lead to improper results in some cases.

In the present study, the participants' attitude was a bit ower than intermediate. Although the participants' 'attitude' was more optimal than the other two variables, the study by Abedian and Dormohamadi reported that $80.2 \%$ of the participants had acceptable attitudes towards cervical cancer (9). The reason for this difference may be the greater knowledge of their participants towards Pap smear. On the other hand, Asgharnia and colleagues found that $24.9 \%$ of the participants showed positive attitude towards Pap smear (4).

Based on the present findings, the participants' performance was really weak. However, Abedian and Dormohamadi showed the performance of the participants as good (54\%), moderate (4\%), and weak $(41.3 \%)$ (9). The findings also confirmed that knowledge and attitude were two effective factors for performance. As mentioned earlier, knowledge is a highly important factor in predicting health behaviors and performing screening methods. Attitude is also an essential factor in predictive behaviors (9). Asgharnia et al. found that $20.4 \%$ of the participants performed Pap smear (4). Barriers for not performing the Pap smear included anxiety (23.6\%), being ashamed $(20.8 \%)$, pain $(12.4 \%)$, cost $(12.9 \%)$, fear of the result $(11.6 \%)$ and not knowing where to undergo this testing (42.2\%) (4). In the present study, the most significant reason for not performing Pap smear was lack of warning signs and symptoms (26.9\%). As it was mentioned before, more than half of the participants mentioned no infectious vaginal discharge.

Participants' age and their spouses' education were found as effective variables for participants' performance. However, age was more effective than spouse's education. This finding is not completely compatible with Abedian and Dormohamadi's study since they showed that knowledge, attitude and performance had a significant relationship with age, but not with the education of participants and their spouses (9).

Most of the participants $(71.2 \%)$ in the present study were familiar with Pap smear as a suitable tool to avoid cervical cancer. Ramezani Tehrani and colleagues declared that $60.8 \%$ of women were already informed about cervical cancer (10).

The results also showed that the physician was the best person for conducting the Pap smear sampling. Participants were also informed about training sessions in health centers; they also considered physicians as the best sources of information about Pap test. According to Zareai, the most informative sources were health workers (5\%), gynecologists (15.9\%) and the participants'relatives $(11.7 \%)$ (3). Abedian and Dormohamadi also found that the staff in health centers and training sessions were the best sources of education (9).

\section{CONCLUSION}

The findings indicated that despite the fact that participants' knowledge and performance regarding cervical cancer were not desirable, their attitudes were estimated as intermediate. Therefore, inviting women to training sessions in health centers, particularly those presented by physicians, and encouraging the health workers to improve their knowledge, attitude and performance of Pap test as means in cervical cancer prevention is highly recommended.

\section{Acknowledgments}

We wish to express our thanks to the Student Research Committee in Sabzevar University of Medical Sciencesfor supporting this study. The authors would like to offer their thanks to participants, too. 


\section{References}

1. Jowzi F, Hashemifard T, Morowatisharifabad M, et al. Factors Associated with Pap Smear Screening Test among Women Aged 15-49 based on Protection Motivation Theory. Hayat, Journal of School of Nursing and Midwifery, Tehran University of Medical Sciences. 2013; 19: 29-40. [Persian]

2. Garcia F, Hatch KD, Berek JS. Intraepithelial disease of th cervix, vagina, and vulva. In: Berek JS. Berek\& Novak's gynecology. Lippincott Williams \& Wilkins, Philadelphia, 2016: 574-618.

3. Zareai M. Women's knowledge and practice of Pap smear test and barriers to performing it in Jahrom. J JahromUniv Med Sci 2014;12:39-47. https://doi.org/10.29252/jmj.12.2.1

4. Asgharnia M, Mirbolouk F, Oudi M, et al. Frequency of Pap smears Test and Attitude about It among Post Partum Women Referred to Alzahra Hospital in Rasht (2009). j. health. 2010; 1:57-65. [Persian]

5. Rakhshani F, Jalilian F, Mirzaei Alavijeh M, et al Pap smear test among Women: An Educational Intervention Based on Health Belief Model. Birjand Univ Med Sci J. 2013; 20: 136-143. [Persian]
6. Karimy M, Shamsi M, Araban M, et al. Pap Smear Test Structures for Measuring Health Belief Model and Factors Affecting Women in Urban Centers Covered Zarandieh. Qom Univ Med Sci J 2012; 6: 52-59. [Persian]

7. Morowatisharifabad M, Norouzi S, Layeghy T, et al. Survey of Cervix Cancer Screening Determinants among 20-65 Years Old Women Based On Health Belief Model in Lordegan, ChaharMahalBakhtiyaree, 2009. Yazd Sci Res Qtly J. 2013; 12: 98-106. [Persian]

8. Nojomi M, Modares Gilani M, Erfani A, et al. The Study of Frequency of Risk Factors of Cervical Cancer Among Women Attending General Hospitals in Tehran, 2005-2006. RJMS. 2007; 14:189-195. [Persian]

9. Abedian Z, Dormohamadi M. Knowledge, attitude and practice of women who referred to health centers of Mashad about pap smear test. IJOGI 2013; 15: 22-28. [Persian]

10. RamezaniTehrani F, Mohammad K, Rahgozar M, et al. Knowledge and practice of Iranian women toward cervical cancer. JRI 2001; 1: 50-56. [Persian] 


\title{
Procena informisanosti žena, učestalosti obavljanja Papanikolau testa i stavova prema ovom pregledu u Sabzevaru, Iran (2015)
}

\author{
Bibi Leila Hoseini ${ }^{1}$, Nematullah Shomoossi², \\ Mohammad Hassan Rakhshani ${ }^{3,4}$, Reihane Beinaghi ${ }^{5}$ \\ ${ }^{1}$ Departman za akušerstvo, Medicinski fakultet, Univerzitet medicinskih nauka u Sabzevaru, Sabzevar, Iran \\ ${ }^{2}$ Departman za opšte kurseve, Medicinski fakultet, Univerzitet medicinskih nauka u Sabzevar, u Sabzevar, Iran \\ ${ }^{3}$ Doktor nauka u biostatistici, Departman za biostatiku, Fakultet za javno zdravlje, \\ Univerzitet medicinskih nauka u Sabzevaru, Sabzevar, Iran \\ ${ }^{4}$ Doktor nauka u biostatistici, Iranski istraživački centar za zdravo starenje, Fakultet za javno zdravlje, \\ ${ }^{5}$ Fakultet za javno zdravlje, Studentski istraživački komitet, \\ Univerzitet medicinskih nauka u Sabzevaru, Sabzevar, Iran
}

\section{S AŽETAK}

Rak grlića materice smatra se čestim karcinomom ženskog reproduktivnog sistema. Takođe, vodi se kao drugi najčešći uzrok smrtnosti od karcinoma kod žena. Smatra se da je u Iranu rak grlića materice četvrti najčešći karcinom kod žena. Stoga je cilj studije bila procena znanja žena, odlaska ginekologu i stavova prema Papanikolau testu $s$ obzirom na značaj Papnikolau testa u prevenciji raka grlića materice, kao $i$ procena uticaja informisanosti žena i stavova prema ovom testu. Ova deskriptivna studija, izvedena u gradu Sabzevar, u Iranu, uključila je 385 žena, koje su bile upućene u zdravstvene centre i ginekološke ordinacije. Upitnik sastavljen i potvrden od strane autora Abediana and Dormohamadia (2013), upotrebljen je za prikupljanje podataka. Deskriptivna i analitička statistika primenjene su za analizu podataka.

Srednje vrednosti za procenu informisanosti, stavova i odlaska ginekologu zbog izvođenja testa iznosile su $2,1 \pm 0,10,66 \pm 0,43$ i $0,70 \pm 0,06$. Starost ispitanica, njihovo obrazovanje i obrazovanje njihovih supružnika su bile efektivne varijable u proceni njihove informisanosti, njihovih stavova i učestalosti obavljanja testa.

Rezultati su ukazali na to, da je uprkos činjenici da informisanost i odlazak ginekologu zbog izvođenja testa nisu bili zadovoljavajući, stav žena je bio prilično prihvatljiv. Stoga se preporučuje edukacija žena u zdravstvenim centrima od strane lekara zajedno sa zdravstvenim osobljem u cilju poboljšanja informisanosti i stavova žena, kao i redovni odlazak ginekologu zbog prevencije raka grlića materice i lečenja.

Ključne reči: informisanost, stav, izvođenje pregleda, Papanikolau test, Sabzevar 